\title{
Mechanisms of antimicrobial resistance in finfish aquaculture environments
}

\author{
Claudio D. Miranda ${ }^{1}$, Alfredo Tello ${ }^{2}$ and Patricia L. Keen ${ }^{3}$ * \\ Department of Aquaculture, Universidad Católica del Norte, Coquimbo, Chile \\ 2 Instituto Tecnológico del Salmón, INTESAL de SalmonChile, Puerto Montt, Chile \\ ${ }^{3}$ Department of Civil Engineering, University of British Columbia, Vancouver, BC, Canada
}

\section{Edited by:}

Marilyn C. Roberts, University of

Washington, USA

\section{Reviewed by:}

Lisa Nonaka, Dokkyo Medical

University, Japan

Henning Sørum, Norwegian School of

Veterinary Science, Norway

\section{*Correspondence:}

Patricia L. Keen, Department of Civil Engineering, University of British

Columbia, 2002 - 6250 Applied

Science Lane, Vancouver, BC V6T 1Z4,

Canada

e-mail: patricia.keen@civil.ubc.ca
Consumer demand for affordable fish drives the ever-growing global aquaculture industry. The intensification and expansion of culture conditions in the production of several finfish species has been coupled with an increase in bacterial fish disease and the need for treatment with antimicrobials. Understanding the molecular mechanisms of antimicrobial resistance prevalent in aquaculture environments is important to design effective disease treatment strategies, to prioritize the use and registration of antimicrobials for aquaculture use, and to assess and minimize potential risks to public health. In this brief article we provide an overview of the molecular mechanisms of antimicrobial resistance in genes found in finfish aquaculture environments and highlight specific research that should provide the basis of sound, science-based policies for the use of antimicrobials in aquaculture.

Keywords: antimicrobials, antimicrobial resistance, fish, aquaculture

\section{INTRODUCTION}

Through a continuous process of expansion, intensification, and diversification, aquaculture has become the fastest-growing food industry in the world (Bostock et al., 2010). With production of new species and the expansion of the production of current species to new geographical locations, the risk of disease and need for treatment continues to increase. This risk is compounded by the uncertainties introduced by global climate change, which may affect the emergence and dynamics of new and existing pathogens (Tirado et al., 2010), and consequently the use of antimicrobials and the prevalence of antimicrobial resistance.

The major concern surrounding the use of antimicrobials in aquaculture is considered to be the potential to favor the development of a reservoir of antimicrobial resistance genes (ARGs) that may be eventually transferred to clinically relevant bacteria (FAO/OIE/WHO, 2006). So far, lack of data, methodological constraints, and the complexity of characterizing exposure pathways have prevented the derivation of quantitative estimates of the risk that this may pose to public health. Nevertheless, there is consensus in the scientific community and international organizations concerned with human health, animal health, and food security that steps should be taken to minimize it (FAO/OIE/WHO, 2006; Smith, 2008; Heuer et al., 2009; WHO, 2011). On a global scale, several of the major classes of antimicrobials are being used or have been used in aquaculture. Among these are sulphonamides, penicillins, macrolides, quinolones, phenicols, and tetracyclines (Sapkota et al., 2008), all of which are listed as critically or highly important antimicrobials in human medicine (WHO, 2011). However, the judicious use of antimicrobials in global aquaculture is important to effectively treat bacterial fish diseases and maintain fish health and welfare.

The molecular mechanism, genomic context, and prevalence of genes conferring resistance to antimicrobials determine their clinical relevance (i.e., whether they confer low- vs. high-level clinical resistance, their ability to be mobilized by lateral gene transfer, and their frequency of occurrence). Thus, knowledge of ARGs from aquaculture environments is important to design and prioritize monitoring programs that may generate data that eventually becomes relevant for performing quantitative risk assessments and develop sound treatment strategies to control fish disease. Within this general scope, we provide this article as an overview of the molecular mechanisms, genomic context, and prevalence of quinolone, tetracycline, and phenicol resistance genes that have been reported to occur in aquaculture environments.

\section{ANTIMICROBIAL RESISTANCE GENES IN AQUACULTURE ENVIRONMENTS}

Quinolones (i.e., oxolinic acid, flumequine, and enrofloxacin), tetracyclines [i.e., oxytetracycline (OTC)], and phenicols (i.e., florfenicol) are among the most widely used antimicrobial compounds in aquaculture, and they have been used extensively to control bacterial fish disease in salmon farming [SERNAPESCA (Chile), 2009; Burridge et al., 2010; Rico et al., 2012]. Although the use of quinolones in salmon farming currently accounts for less than $1 \%$ of the overall use of antimicrobials, they continue to be used in aquaculture production in several Asian countries [SERNAPESCA (Chile), 2009; Burridge et al., 2010; Rico et al., 2012]. Quinolones, tetracyclines, and phenicols have been reported to be selective for a variety of ARGs and tend to occur in mobile genetic elements that favor their dissemination (i.e., transposons, plasmids, and integrons; Cloeckaert et al., 2000; Chopra and Roberts, 2001; Kümmerer, 2004; Schwarz et al., 2004; Roberts, 2005).

\section{QUINOLONE RESISTANCE}

The protein targets of quinolones are the bacterial enzymes, DNA gyrase and topoisomerase IV. DNA gyrase is a tetrameric enzyme 
encoded by the gyrA and gyrB genes, and its main activity is to catalyze the negative supercoiling of bacterial DNA. Topoisomerase IV is also a tetrameric enzyme and it is encoded by the parC and parE genes; its function is to decatenate and relax the activity of daughter replicons following DNA replication (Anderson et al., 1998; Hawkey, 2003).

The acquisition of quinolone resistance is primarily due to chromosomal mutations in topoisomerases genes (i.e., gyrA, gyrB, parC, and parE) and mutations that reduce drug accumulation by decreasing uptake or increasing efflux (Drlica and Zhao, 1997; Ruiz, 2003). Additionally, at least three mechanisms of quinolone resistance are known to be plasmid encoded: (1) Qnr proteins; (2) AAC(6)-Ib-cr aminoglycoside acetyltransferases; and (3) QepA and OqxAB efflux pumps. Qnr proteins protect DNA gyrase and type IV topoisomerase from quinolone inhibition (Tran and Jacoby, 2002; Jacoby, 2005) and the AAC(6)-Ib-cr determinant acetylates several fluoroquinolones. Plasmid-encoded QepA and OqxAB are active efflux pumps that may extrude hydrophilic fluoroquinolones such as enrofloxacin (Li, 2005; Poirel et al., 2008, 2012; Cattoir and Nordmann, 2009; Rodríguez-Martínez et al., 2011).

Various point mutations in the quinolone resistancedetermining regions of the $g y r A$ and/or parC genes have been detected in quinolone-resistant strains of the fish pathogens Aeromonas hydrophila, Vibrio anguillarum, and V. parahaemolyticus (Okuda et al., 1999; Rodkhum etal., 2008; Lukkana etal., 2012). Levels of quinolone resistance in Gram-negative bacteria are suggested to be high when associated with point mutations in both the gyrA and parC genes, whereas only an intermediate level of resistance is associated with point mutations in the gyrA gene only. However, high-level resistance to oxolinic acid associated with a single mutation in the gyrA gene has been reported for strains of the fish pathogens Aeromonas salmonicida, Edwardsiella tarda, and Photobacterium damselae (Oppegaard and Sørum, 1994; Goñi-Urriza et al., 2002; Kim et al., 2005, 2011; Ozanne et al., 2005). The extensive administration of quinolones in fish farming has been linked to increased mutations in DNA gyrase and topoisomerase IV in quinolone-resistant fish pathogens such as Yersinia ruckeri, Flavobacterium psychrophilum, and V. anguillarum (Gibello et al., 2004; Izumi and Aranishi, 2004; Colquhoun et al., 2007; Izumi et al., 2007; Shah et al., 2012).

Plasmid-mediated quinolone resistance in bacteria associated with fish farms has been detected in several countries. Ishida et al. (2010) detected the qnr and $a a c\left(6^{\prime}\right)$ - $I b-c r$ resistance determinants in bacterial strains isolated from fish farm water samples in Egypt. Recently, Buschmann et al. (2012) reported the occurrence of topoisomerase protection genes $q n r A$, qnrB, and $q n r S$, the putative enzymatic inactivation gene $a a c(69)-I b-c r$ and the efflux pump gene oqxA among strains isolated from un-polluted and fish farm-impacted marine sediments in Chile. Jiang et al. (2012) found a high prevalence of $q n r B$ and $q n r S$ genes in Escherichia coli strains recovered from Chinese farmed fish while qnrD and $a a c\left(6^{\prime}\right)-I b-c r$ genes occurred less frequently. Han et al. (2012) found 17 strains encoding chromosomal mutations in gyrA, 11 strains encoding mutations in parC, and a few strains carrying the qnrS1-like and qnrS2 genes among 33 Aeromonas spp. isolated from diseased fish and from water samples. The identification of
QnrS determinants in Aeromonas spp. suggests that they may act as an environmental reservoir of $q n r S$ genes, as already described for tet genes (Rhodes et al., 2000; Schmidt et al., 2001a). Some $q n r$ genes have also been described in the Vibrionaceae family and it is suggested that water-borne Vibrionaceae may constitute a natural reservoir for Qnr-like quinolone-resistance determinants (Poirel et al., 2005; Cattoir et al., 2007; Cattoir and Nordmann, 2009). Evidence suggests that $q n r$-plasmids are most commonly integron associated and carry multiple resistance determinants, providing resistance to several classes of antimicrobials, including beta-lactams and aminoglycosides (Li, 2005).

\section{TETRACYCLINE RESISTANCE}

Oxytetracycline is a broad-spectrum bacteriostatic antimicrobial, active against a wide variety of Gram-positive and Gram-negative bacteria, which is extensively used in fish farming. Tetracyclines bind reversibly to the $70 \mathrm{~S}$ ribosome of prokaryotes and block protein synthesis (Chopra, 1985; Roberts, 1996).

Mechanisms of tetracycline resistance include active efflux, ribosomal protection, ribosomal RNA mutations, and tetracycline inactivation (Speer and Salyers, 1989; Salyers et al., 1990; Burdett, 1991; Levy, 1992; Speer et al., 1992; Taylor and Chau, 1996). Tetracycline resistance in fish farm-associated bacteria has been found to be mainly mediated by one or more of the Tet family of proton-dependent efflux pumps or via ribosomal protection by cytoplasmic proteins found widely in Gram-negative bacteria (Roberts, 2005; Roberts et al., 2012).

Several tet determinants have been identified in fish farm bacteria from a number of geographical locations and fish species (DePaola et al., 1988; Adams etal., 1998; Rhodes et al., 2000; Schmidt et al., 2001a; Furushita et al., 2003; Miranda et al., 2003; Akinbowale etal., 2007; Seyfried et al., 2010; Gao et al., 2012). The genes tet $(\mathrm{A}), \operatorname{tet}(\mathrm{B}), \operatorname{tet}(\mathrm{E}), \operatorname{tet}(\mathrm{H}), \operatorname{tet}(\mathrm{L})$, tet $(34)$, and tet $(35)$ were found in tetracycline-resistant bacteria isolated from Chilean salmon farms (Miranda et al., 2003). Recently, Seyfried et al. (2010) detected the presence of tet $(\mathrm{A}), \operatorname{tet}(\mathrm{B}), \operatorname{tet}(\mathrm{D}), \operatorname{tet}(\mathrm{E})$, $\operatorname{tet}(\mathrm{G}), \operatorname{tet}(\mathrm{M}), \operatorname{tet}(\mathrm{O}), \operatorname{tet}(\mathrm{Q}), \operatorname{tet}(\mathrm{S})$, and tet $(\mathrm{W})$ genes in medicated and non-medicated feed samples and water samples from non-commercial fish farms in the United States. Similarly, Jun et al. (2004) found a high prevalence of tet(A) and tet(D) genes associated with mobile plasmids and tet $(\mathrm{B})$ and tet $(\mathrm{G})$ genes associated with non-mobile elements in Edwardsiella tarda strains isolated from fish farms in Korea. Nonaka et al. (2007) found a high incidence of tet $(\mathrm{M})$-carrying Vibrio strains in fish farms and Agersø et al. (2007) detected tet(E) in Aeromonas strains from Danish fish farms associated with large plasmids capable of horizontal transfer to Escherichia coli. Nawaz et al. (2009) found a high prevalence of tet $(\mathrm{B})$ and, to a lesser extent, tet $(\mathrm{A}), \operatorname{tet}(\mathrm{C})$ and the co-occurrence of tet (A) and tet(B) in Escherichia coli isolated from farm-raised catfish. Kim et al. (2004) reported the occurrence of tet $(\mathrm{M})$ and tet $(\mathrm{S})$ in tetracycline-resistant bacteria from fish farms in Korea and Nonaka and Suzuki (2002) found the novel OTCresistance determinant tet(34) in a Vibrio strain isolated from cultured yellowtail (Seriola quinqueradiata).

The spread of tet genes is often facilitated by their location on mobile genetic elements, such as plasmids and transposons (Roberts, 1994; DePaola and Roberts, 1995; Chopra and Roberts, 
2001). Tn1721 and Tn1721-like elements, for example, are known to play a significant role in the global dissemination of the tet $(\mathrm{A})$ gene (Rhodes et al., 2000; Sørum et al., 2003; Chenia and Vietze, 2012). Miranda etal. (2003) found the tet $(\mathrm{H})$ gene as part of the transposon Tn5706 in Moraxella and Acinetobacter strains isolated from salmon farms. In addition, they were able to transfer tet(B) and tet(34) genes from strains of Serratia liquefaciens, Pseudomonas pseudoalcaligenes, and Brevundimonas vesicularis. Similarly, Furushita et al. (2003) transferred tet(B), tet(D), and tet $(\mathrm{Y})$ genes from bacterial isolates from different Japanese fish farms by conjugation and Adams et al. (1998) reported that various OTC-resistant isolates of Aeromonas salmonicida transferred R-plasmids carrying the tet(A) gene to environmental and clinical isolates of Aeromonas spp. Class 1 integrons harboring different combinations of the resistance gene cassettes ant $\left(3^{\prime \prime}\right) I a, a a c\left(6^{\prime \prime}\right) I a$, dhfr 1 , oxa $2 a$, and/or pse 1 and tet genes were also detected in a large number of plasmid bearing Aeromonas spp. strains isolated from tilapia, trout, and koi cultures in South Africa (Jacobs and Chenia, 2007). In Edwardsiella ictaluri strains isolated from diseased freshwater catfish in Vietnam, Dung et al. (2009) found the tet(A) gene associated with a high-molecular weight plasmid belonging to the IncK group. In addition, all strains were able to transfer their tet(A)-carrying plasmids to Escherichia coli recipients.

Several studies have also reported the co-occurrence of tetracycline and sulphonamide resistances genes. Agers $\emptyset$ and Petersen (2007) showed that tet(39) and sul2 genes located on plasmids of different sizes to be common among clonally distinct Acinetobacter spp. from fish farms in Thailand. Su et al. (2011) detected the genes tet(A), tet(C), and the sulphonamide-resistance gene, sul2, in more than $50 \%$ of the strains of Enterobacteriaceae they isolated from fish farms in China. Gao et al. (2012) recently reported the co-occurrence of tetracycline- and sulphonamide-resistance genes in Bacillus species isolated from aquaculture farms in China.

\section{PHENICOL RESISTANCE}

Florfenicol is a synthetic fluorinated analog of chloramphenicol whose bacteriostatic activity is based on a reversible binding to the $50 \mathrm{~S}$ subunit of $70 \mathrm{~S}$ bacterial ribosomes that prevents peptide elongation (Schwarz et al., 2004). The replacement of a hydroxyl group with a fluorine atom protects florfenicol from inactivation by chloramphenicol acetyltransferases (CATs), a common mechanism of bacterial resistance to chloramphenicol (Shaw and Leslie, 1991; Schwarz et al., 2004). The effectiveness of florfenicol against a number of relevant fish pathogens makes it a very valuable drug for the fish farming industry (Fukui et al., 1987; Nordmo et al., 1994; Samuelsen et al., 1998, 2003; Bruun et al., 2000; Gaunt et al., 2003; McGinnis et al., 2003; Michel et al., 2003; Samuelsen and Bergh, 2004).

Mechanisms of resistance to florfenicol include specific and non-specific drug transporters, RNA methyltransferases, and specific hydrolases (Paulsen et al., 1996; Schwarz et al., 2004; Poole, 2005; Long etal., 2006; Tao etal., 2012). Genes floR and fexA belong to the major facilitator superfamily and code for efflux proteins that export florfenicol out of the cell (Schwarz etal., 2004). The gene $c f r$, which has been shown to be an RNA methyltransferase that belongs to the recently discovered radical
S-adenosylmethionine (SAM) superfamily of proteins (Sofia et al., 2001), inhibits ribose methylation and thereby causes resistance to florfenicol, chloramphenicol, and clindamycin (Long et al., 2006).

Most studies of florfenicol resistance in fish farming have reported the occurrence of the floR gene. Dang et al. (2007) detected the floR gene in tetracycline-resistant bacteria isolated from aquaculture sites in China, and Ishida et al. (2010) detected the floR gene in four strains of Gram-negative bacteria isolated from fish farms in Africa. In North America, McIntosh et al. (2008) reported the occurrence of Aeromonas salmonicida strains carrying a conjugative IncA/C plasmid harboring floR, sul2, and tet $A$ genes that were transferable to Aeromonas hydrophila and Edwardsiella tarda. Welch et al. (2009) detected IncA/C plasmid-mediated florfenicol resistance in the catfish pathogen Edwardsiella ictaluri, and Gordon et al. (2008) reported a multiresistant Aeromonas bestiarum strain carrying a plasmid harboring the floR, tet $Y$, sul2, and $s \operatorname{tr} A-s \operatorname{tr} B$ resistance genes. A relatively recent study showed that many florfenicol-resistant bacterial strains isolated from Chilean salmon farms carried the floR gene, whereas others possessed non-specific efflux pumps that conferred florfenicol resistance (Fernández-Alarcón et al., 2010). In fish farm impacted marine sediments, Buschmann et al. (2012) recently reported the occurrence of several strains containing plasmid-borne floR, tet, and $q n r$ genes.

\section{PRIORITIZING RESEARCH AND POLICY NEEDS}

The studies discussed in the previous sections support the hypothesis that fish farms represent a reservoir of diverse ARGs, many of which may be readily mobilized by lateral gene transfer. Given the extent of global aquaculture and its fast-paced growth, it is imperative that research needs with regards to the use of antimicrobials and the emergence and potential spread of antimicrobial resistance are prioritized. This research should form the basis of sound, science-based policies that contribute to the sustainability of the aquaculture industry and minimize risks to public health. Further studies are needed to explore the prevalence of antimicrobial resistance in zoonotic fish pathogens such as Aeromonas hydrophila, Edwardsiella tarda, Mycobacterium fortuitum, Mycobacterium marinum, Photobacterium damselae, Pseudomonas fluorescens, and Streptococcus iniae (Austin and Austin, 2012). Moreover, there are important knowledge gaps regarding the co-occurrence of antimicrobial-resistant bacteria from aquaculture environments with human pathogens throughout production cycles and across a range of aquaculture environments, the transfer rate of resistance genes between aquaculture and clinically relevant bacteria under field or semi-field conditions, and the epidemiology of antimicrobial resistance in areas of intense aquaculture activity.

Good management strategies can make a significant contribution to minimize the use of antimicrobials in fish and the emergence and spread of antimicrobial resistance in aquaculture environments. Among these precautionary practices are the use of "good quality" fish stocks, reducing stocking densities, maintaining overall good environmental conditions (e.g., dissolved $\mathrm{O}_{2}$ levels), the implementation of proper biosecurity measures, the development of effective vaccines and vaccination programs, and 
the rotation of antimicrobial compounds in the treatment of fish disease. Although the use of antimicrobials in human medicine places constraints on the type of antimicrobials that may be used in veterinary medicine, the rotation of antimicrobials in aquaculture may play an important role in reducing the chances of

\section{REFERENCES}

Adams, C. A., Austin, B., Meaden, P. G., and McIntosh, D. (1998). Molecular characterization of plasmidmediated oxytetracycline resistance in Aeromonas salmonicida. Appl. Environ. Microbiol. 64, 4194-4201.

Agersø, Y., Bruun, M. S., Dalsgaard, I., and Larsen, J. L. (2007). The tetracycline resistance gene tet(E) is frequently occurring and present on large horizontally transferable plasmids in Aeromonas spp. from fish farms. Aquaculture 266, 47-52. doi: 10.1016/j.aquaculture.2007.01.012

Agersø, Y., and Petersen, A. (2007). The tetracycline resistance determinant Tet 39 and the sulphonamide resistance gene sulII are common among resistant Acinetobacter spp. isolated from integrated fish farms in Thailand. J. Antimicrob. Chemother. 59, 23-27. doi: $10.1093 / \mathrm{jac} /$ dkl419

Akinbowale, O. L., Peng, H., and Barton, M. D. (2007). Diversity of tetracycline resistance genes in bacteria from aquaculture sources in Australia. J. Appl. Microbiol. 103, 2016-2025. doi: 10.1111/j.1365-2672.2007.03445.x

Anderson, V. E., Gootz, T. D., and Osheroff, N. (1998). Topoisomerase IV catalysis and the mechanism of quinolone action. J. Biol. Chem. 273, 17879-17885. doi: $10.1074 /$ jbc.273.28.17879

Austin, B., and Austin, D. (2012). Bacterial Fish Pathogens: Disease of Farmed and Wild Fish. Dordrecht: Springer Science + Business Media.

Bostock, J., McAndrew, B., Richards, R., Jauncey, K., Telfer, T., Lorenzen, K., et al. (2010). Aquaculture: global status and trends. Philos. Trans. R. Soc. Lond. B Biol. Sci. 365, 2897-2912. doi: 10.1098/rstb.2010.0170

Bruun, M. S., Schmidt, A. S., Lone Madsen, L., and Dalsgaard, I. (2000). Antimicrobial resistance patterns in Danish isolates of Flavobacterium psychrophilum. Aquaculture 187, 201-212. doi: 10.1016/S00448486(00)00310-0

Burdett, V. (1991). Purification and characterization of tet(M), a protein that renders ribosomes resistant to tetracycline. J. Biol. Chem. 266, 2872-2877.

Burridge, L., Weis, J. S., Cabello, F., Pizarro, J., and Bostick, K. (2010). Chemical use in salmon aquaculture: a review of current practices and possible environmental effects. Aquaculture 306, 7-23. doi: 10.1016/j.aquaculture.2010.05.020

Buschmann, A. H., Tomova, A., López, A., Maldonado, M. A., Henríquez, L. A., Ivanova, L., et al. (2012). Salmon aquaculture and antimicrobial resistance in the marine environment. PLoS ONE 7:e42724. doi: 10.1371/journal.pone.0042724

Cattoir, V., and Nordmann, P. (2009) Plasmid-mediated quinolone resistance in Gram-negative bacterial Chem. 16, 1028-1046. doi: 10.2174/ 092986709787581879

Cattoir, V., Poirel, L., Mazel, D., Soussy, C. J., and Nordmann, P. (2007). Vibrio splendidus as the source of plasmid-mediated QnrSlike quinolone resistance determinants. Antimicrob. Agents Chemother. AAC.00070-07

Chenia, H. Y., and Vietze, C. (2012). Tetracycline resistance determinants of heterotrophic bacteria isolated from a South African tilapia aquaculture system. Afr. J. Microbiol. Res. 6, 6761-6768. doi: 10.5897/AJMR10.840

Chopra, I. (1985). "Mode of action of the tetracyclines and the nature of bacterial resistance to them," in The Tetracyclines. Handbook of Experimental Pharmacology, Vol. 78, eds J. J. Hlavka and J. H. Boothe (Berlin: Springer-Verlag KG), 317-392.

Chopra, I., and Roberts, M. C. (2001). Tetracycline antibiotics: mode of action, applications, molecular biology, and epidemiology of bacterial resistance. Microbiol. Mol. Biol. Rev. 65, 232-260. doi: 10.1128/

Cloeckaert, A., Baucheron, S., and Chaslus-Dancla, E. (2001). Nonenzymatic chloramphenicol resistance mediated by IncC plasmid R55 is encoded by a flo R gene variant. Antimicrob. Agents Chemother. 45, 2381-2382. doi: 10.1128/ AAC.45.8.2381-2382.2001

Cloeckaert, A., Baucheron, S., Flaujac, S., Schwarz, S., Kehrenberg, C., Martel, J., et al. (2000). Plasmid-mediated florfenicol resistance encoded by the floR gene in Escherichia coli isolated from cattle. Antimicrob. Agents Chemother. 44, 2858-2860. species: an update. Curr. Med. 51, 2650-2651. doi: 10.1128/ MMBR.65.2.232-260.2001

selection, co-selection, and dissemination of antimicrobial resistance. In this context, it is also important that efforts are directed toward creating incentives for the development and registration of antimicrobials for aquaculture use in addition to implementation of antimicrobial stewardship practices.

doi: $10.1128 /$ AAC.44.10.2858-2860. 2000

Colquhoun, D. J., Aarflot, L., and Melvold, C. F. (2007). gyrA and parC mutations and associated quinolone resistance in Vibrio anguillarum serotype O2b strains isolated from farmed Atlantic cod (Gadus morhua) in Norway. Antimicrob. Agents Chemother. 51, 2597-2599. doi: 10.1128/AAC.00315-07

Dang, H., Zhang, X., Song, L., Chang, Y., and Yang, G. (2007). Molecular determination of oxytetracyclineresistant bacteria and their resistance genes from mariculture environments of China. J. Appl. Microbiol. 103, 2580-2592. doi: 10.1111/j.13652672.2007.03494.x

DePaola, A., Flynn, P. A., McPhearson, R. M., and Levy, S. B. (1988). Phenotypic and genotypic characterization of tetracycline- and oxytetracycline resistant Aeromonas hydrophila from cultured channel catfish (Ictalurus punctatus) and their environments. Appl. Environ. Microbiol. 54, 18611863.

DePaola, A., and Roberts, M. C. (1995). Class D and E tetracycline resistance determinants in Gram-negative catfish pond bacteria. Mol. Cell. Probes 9, 311-313. doi: 10.1016/S08908508(95)91572-9

Drlica, K., and Zhao, X. L. (1997). DNA gyrase, topoisomerase IV, and the 4-quinolones. Microbiol. Rev. 61, 377-392.

Dung, T. T., Haesebrouck, F., Sorgeloos, P., Tuan, N. A., Pasmans, F., Smet, A., etal. (2009). IncK plasmidmediated tetracycline resistance in Edwarsiella ictaluri isolates from diseased freshwater catfish in Vietnam. Aquaculture 295, 157-159. doi: 10.1016/j.aquaculture.2009.07.010

FAO/OIE/WHO. (2006). Report of a Joint FAO/OIE/WHO Expert Consultation on Antimicrobial Use in Aquaculture and Antimicrobial Resistance: Seoul, Republic of Korea, June 13-16, 2006. Seoul: WHO.

Fernández-Alarcón, C., Miranda, C. D., Singer, R. S., López, Y., Rojas, R., Bello, H., et al. (2010). Detection of the flo $\mathrm{R}$ gene in a diversity of florfenicol resistant Gram-negative bacilli from freshwater salmon farms in Chile. Zoonoses Public Health 57, 181-188. doi: 10.1111/j.18632378.2009.01243.x
Fukui, H., Fujihara, Y., and Kano, T. (1987). In vitro and in vivo antibacterial activities of florfenicol, a new fluorinated analog of thiamphenicol, against fish pathogens. Fish Pathol. 22, 201-207. doi: 10.3147/jsfp. 22.201

Furushita, M., Shiba, T., Maeda, T., Yhata, M., Kaneoka, A., Takahashi, Y., et al. (2003). Similarity of tetracycline resistance genes isolated from fish farm bacteria to those from clinical isolates. Appl. Environ. Microbiol. 69, 5336-5342. doi: 10.1128/AEM.69.9.5336-5342.2003

Gao, P., Mao, D., Luo, Y., Wang, L., $\mathrm{Xu}, \mathrm{B}$, and $\mathrm{Xu}, \mathrm{L}$. (2012). Occurrence of sulphonamide and tetracycline-resistant bacteria and resistance genes in aquaculture environment. Water Res. 46, 2355-2364. doi: 10.1016/j.watres.2012.02.004

Gaunt, P., Endris, R., Khoo, L., Leard, T., Jack, S., Santucci, T., et al. (2003). Preliminary assessment of the tolerance and efficacy of florfenicol against Edwardsiella ictaluri administered in feed to channel catfish. J. Aquat. Anim. Health 15, 239-247. doi: 10.1577/H03-022

Gibello, A., Porrero, M. C., Blanco, M. M., Vela, A. I., Liébana, P., Moreno, M. A., et al. (2004). Analysis of the gyrA gene of clinical Yersinia ruckeri isolates with reduced susceptibility to quinolones. Appl. Environ. Microbiol. 70, 599-602. doi: 10.1128/AEM.70.1.599-602.2004

Goñi-Urriza, M., Arpin, C., Capdepuy, M., Dubois, V., Caumette, P., and Quentin, C. (2002). Type II topoisomerase quinolone resistancedetermining regions of Aeromonas caviae, A. hydrophila and A. sobria complexes and mutations associated with quinolone resistance. Antimicrob. Agents Chemother. 46, 350-359. doi: 10.1128/AAC.46.2.350-359.2002 PMCid:PMC127024

Gordon L, Cloeckaert A, Doublet, B., Schwarz, S., Agnès Bouju-Albert, A., Ganière, J. P., et al. (2008). Complete sequence of the floR-carrying multiresistance plasmid pAB5S9 from freshwater Aeromonas bestiarum. J. Antimicrob. Chemother. 62, 65-71. doi: 10.1093/jac/dkn166

Han, J. E., Kim, J. H., Cheresca, C. H., Shin, S. P., Jun, J. W., Chai, J. Y., et al. (2012). First description of the qnrS-like (qnrS5) gene and analysis 
of quinolone resistance-determining regions in motile Aeromonas spp. from diseased fish and water. Res. Microbiol. 163, 73-79. doi: 10.1016/j.resmic.2011.09.001

Hawkey, P. M. (2003). Mechanisms of quinolone action and microbial response. J. Antimicrob. Chemother. 51, S1, 29-35. doi: 10.1093/jac/dkg207

Heuer, O. E., Kruse, H., Grave, K., Collignon, P., Karunasagar, I., and Angulo, F. J. (2009). Human health consequences of use of antimicrobial agents in aquaculture. Clin. Infect. Dis. 49, 1248-1253. doi: 10.1086/605667

Ishida, Y., Ahmed, A. M., Mahfouz, N. B., Kimura, T., El-Khodery, S. A., Moawad, A. A., et al. (2010). Molecular analysis of antimicrobial resistance in Gram-negative bacteria isolated from fish farms in Egypt. J. Vet. Med. Sci. 72, 727-734. doi: 10.1292/jvms.09-0538

Izumi, S., and Aranishi, F. (2004). Relationship between gyrA mutations and quinolone resistance in Flavobacterium psychrophilum isolates. Appl. Environ. Microbiol. 70, 3968-3972. doi: 10.1128/AEM.70.7.3968-3972. 2004

Izumi, S., Ouchi, S., Kuge, T., Arai, H., Mito, T., Fujii, H., et al. (2007). PCR-RFLP genotypes associated with quinolone resistance in isolates of Flavobacterium psychrophilum. J. Fish Dis. 30, 141147. doi: 10.1111/j.1365-2761.2007. 00797.x

Jacobs, L., and Chenia, H. Y. (2007). Characterization of integrons and tetracycline resistance determinants in Aeromonas spp. isolated from South African aquaculture systems. Int. J. Food Microbiol. 114, 295-306. doi: 10.1016/j. ijfoodmicro.2006.09.030

Jacoby, G. A. (2005). Mechanisms of resistance to quinolones. Clin. Infect. Dis. 41, S120-S126. doi: 10.1086/ 428052

Jiang, H. X., Tang, D., Liu, Y. H., Zhang, X. H., Zeng, Z. L., Xu, L., et al. (2012). Prevalence and characteristics of $\beta$-lactamase and plasmid-mediated quinolone resistance genes in Escherichia coli isolated from farmed fish in China. J. Antimicrob. Chemother. 67, 2350-2353. doi: 10.1093/jac/dks250

Jun, L. J., Jeong, J. B., Huh, M. D., Chung, J. K., Choi, D. L., Lee, C. H., et al. (2004). Detection of tetracycline-resistance determinants by multiplex polymerase chain reaction in Edwardsiella tarda isolated from fish farms in Korea. Aquaculture 240, 89 100. doi: 10.1016/j.aquaculture.2004 07.025

Kim, J. H., Hwang, S. Y., Son, J. S., Han, J. E., Jun, J. W., Shin, S. P., et al. (2011). Molecular characterization of tetracycline- and quinolone-resistant Aeromonas salmonicida isolated in Korea. J. Vet. Sci. 12, 41-48. doi: 10.4142/jvs.2011.12.1.41

Kim, M. J., Hirono, I., and Aoki, T. (2005). Detection of quinolone-resistant genes in Photobacterium damselae subsp. piscicida strains by targeting-induced local lesions in genomes. J. Fish Dis. 28, 463-471. doi: 10.1111/j.13652761.2005.00652.x

Kim, S. R., Nonaka, L., and Suzuki S. (2004). Occurrence of tetracycline resistance genes tet $(\mathrm{M})$ and tet(S) in bacteria from marine aquaculture sites. FEMS Microbiol. Lett. 237, 147-156. doi: 10.1111/j.1574 6968.2004.tb09690.x

Kümmerer, K. (2004). Resistance in the environment. J. Antimicrob. Chemother. 54, 311-320. doi: 10.1093/jac/dkh325

Levy, S. B. (1992). Active efflux mechanisms for antimicrobial resistance. Antimicrob. Agents Chemother 36, 695-703. doi: 10.1128/AAC.36. 4.695

Li, X. Z. (2005). Quinolone resistance in bacteria: emphasis on plasmidmediated mechanisms. Int. J. Antimicrob. Agents 25, 453-463. doi: 10.1016/j.ijantimicag.2005.04.002

Long, K. S., Poehlsgaard, J., Kehrenberg, C., Schwarz, S., and Vester, B. (2006). The Cfr rRNA methyltransferase confers resistance to phenicols, lincosamides, oxazolidinones, pleuromutilins, and streptogramin A antibiotics. Antimicrob. Agents Chemother. 50, 2500-2505. doi: 10.1128/AAC.00131-06

Lukkana, M., Wongtavatchai, J., and Chuanchuen, R. (2012). Class 1 integrons in Aeromonas hydrophila isolates from farmed Nile tilapia (Oreochromis nilotica). J. Vet. Med. Sci. 74, 435-440. doi: 10.1292/jvms. 11-044

McGinnis, A., Gaunt, P., Santucci, T., Simmons, R., and Endris, R. (2003). In vitro evaluation of the susceptibility of Edwardsiella ictaluri, etiological agent of enteric septicemia in channel catfish, Ictalurus punctatus (Rafinesque), to florfenicol. J. Vet. Diagn. Invest. 15, 576-579. doi: $10.1177 / 104063870301500612$

McIntosh, D., Cunningham, D., Ji, B., Fekete, F. A., Parry, E. M. Clark, S. E., et al. (2008). Transferable, multiple antibiotic and mercury resistance in Atlantic Canadian isolates of Aeromonas salmonicida subsp. Salmonicida is associated with carriage of an IncA/C plasmid similar to the Salmonella enterica plasmid pSN254. J. Antimicrob. Chemother. 61, 1221-1228. doi: 10.1093/jac/dkn123

Michel, C., Kerouault, B., and Martin, C. (2003). Chloramphenicol and florfenicol susceptibility of fish-pathogenic bacteria isolated in France: comparison of minimum inhibitory concentration, using recommended provisory standards for fish bacteria. J. Appl. Microbiol. 95, 1008-1015. doi: 10.1046/j.13652672.2003.02093.x

Miranda, C. D., Kehrenberg, C., Ulep, C., Schwarz, S., and Roberts, M. C. (2003). Diversity of tetracycline resistance genes in bacteria from Chilean salmon farms. Antimicrob. Agents Chemother. 47, 883-888. doi: 10.1128/AAC.47.3.883-888.2003

Nawaz, M., Khan, A. A., Khan, S. Sung, K., Kerdahi, K., and Steele, R. (2009). Molecular characterization of tetracycline-resistant genes and integrons from avirulent strains of Escherichia coli isolated from catfish. Foodborne Pathog. Dis. 6, 553-559. doi: 10.1089/fpd.2008.0204

Nonaka, L., Ikeno, K., and Suzuki, S. (2007). Distribution of tetracycline resistance gene, tet $(\mathrm{M})$, in Grampositive and Gram-negative bacteria isolated from sediment and seawater at a coastal aquaculture site in Japan. Microbes Environ. 22, 355-364. doi: 10.1264/jsme2.22.355

Nonaka, L., and Suzuki, S. (2002). New $\mathrm{Mg}^{+}{ }^{-}$-dependent oxytetracycline resistance determinant Tet 34 in Vibrio isolates from marine fish intestinal contents. Antimicrob. Agents Chemother. 46, 1550-1552. doi: 10.1128/AAC.46.5. 1550-1552.2002

Nordmo, R., Varma, K. J., Sutherland, I. H., and Brokken, E. S. (1994). Florfenicol in Atlantic salmon, Salmo salar L.: field evaluation of efficacy against furunculosis in Norway. J. Fish Dis. 17, 239 244. doi: 10.1111/j.1365-2761.1994. tb00219.x

Okuda, J., Hayakawa, E., Nishibuchi, M., and Nishino, T. (1999). Sequence analysis of the gyrA and parC homologues of a wild type strain of Vibrio parahaemolyticus and its fluoroquinolone-resistant mutants. Antimicrob. Agents. Chemother. 43, 1156-1162.

Oppegaard, H., and Sørum, H. (1994). gyrA mutations in quinoloneresistant isolates of the fish pathogen
Aeromonas salmonicida. Antimicrob. Agents Chemother. 38, 2460-2464. doi: 10.1128/AAC.38.10.2460

Ozanne, B., Benveniste, R., Tipper, D., and Davies, J. (2005). Molecular cloning of the gyrA gene and characterization of its mutation in clinical isolates of quinolone-resistant Edwarsiella tarda. Dis. Aquat. Org. 67, 259-266. doi: 10.3354/dao067259

Paulsen, I. T., Brown, M., and Skurray, R. (1996). Proton-dependent multidrug efflux systems. Microbiol. Rev. 60, 575-608.

Poirel, L., Cattoir, V., and Nordmann, P. (2008). Is plasmid-mediated quinolone resistance a clinically significant problem? Clin. Microbiol. Infect. 14, 295-297. doi: 10.1111/j.1469-0691.2007.01930.x

Poirel, L., Cattoir, V., and Nordmann, P. (2012). Plasmid-mediated quinolone resistance: interactions between human, animal, and environmental ecologies. Front. Microbiol. 3:24. doi: 10.3389/fmicb.2012.00024

Poirel, L., Liard, A., RodriguezMartinez, J. M., and Nordmann, P. J. (2005). Vibrionaceae as a possible source of Qnr-like quinolone resistance determinants. J. Antimicrob. Chemother. 56, 1118-1121. doi: 10.1093/jac/dki371

Poole, K. (2005). Efflux-mediated antimicrobial resistance. J. Antimicrob. Chemother. 56, 20-51. doi: 10.1093/jac/dki171

Rhodes, G., Huys, G., Swings, J., McGann, P., Hiney, M., Smith, P., et al. (2000). Distribution of oxytetracycline resistance plasmids between aeromonads in hospital and aquaculture environments: implication of Tn1721 in dissemination of the tetracycline resistance determinant Tet A. Appl. Environ. Microbiol. 66, 3883-3890. doi: 10.1128/AEM.66.9.3883-3890.2000

Rico, A., Satapornvanit, K., Haque, M. M., Min, J., Nguyen, P. T., Telfer, T. C., et al. (2012). Use of chemicals and biological products in Asian aquaculture and their potential environmental risks: a critical review. Rev. Aquac. 4, 75-93. doi: 10.1111/j.17535131.2012.01062.x

Roberts, M. C. (1994). Epidemiology of tetracycline-resistance determinants. Trends Microbiol. 2, 353-357. doi: 10.1016/0966-842X(94)90610-6

Roberts, M. C. (1996). Tetracycline resistance determinants: mechanisms of action, regulation of expression, genetic mobility, and distribution. FEMS Microbiol. Rev. 19, 1-24. doi: 10.1111/j.1574-6976.1996.tb00251.x Roberts, M. C. (2005). Update on acquired tetracycline resistance 
genes. FEMS Microbiol. Lett. 245, 195-203. doi: 10.1016/j.femsle.2005. 02.034

Roberts, M. C., Schwarz, S., and Aarts, H. J. M. (2012). Erratum: acquired antibiotic resistance genes: an overview. Front. Microbiol. 3:384. doi: 10.3389/fmicb.2012.00384

Rodkhum, C., Maki, T., Hirono, I., and Aoki, T. (2008). gyrA and parC associated with quinolone resistance in Vibrio anguillarum. J. Fish Dis. 31, 395-399. doi: 10.1111/j.13652761.2007.00843.x

Rodríguez-Martínez, J. M., Cano, M. E., Velasco, C., Martínez-Martínez, L., and Pascual, A. (2011). Plasmidmediated quinolone resistance: an update. J. Infect. Chemother. 17, 149 182. doi: 10.1007/s10156-010-0120-2

Ruiz, J. (2003). Mechanisms of resistance to quinolones: target alterations, decreased accumulation and DNA gyrase protection. J. Antimicrob. Chemother. 51, 1109-1117. doi: 10.1093/jac/dkg222

Salyers, A. A., Speer, B. S., and Shoemaker, N. B. (1990). New perspectives in tetracycline resistance. Mol. Microbiol. 4, 151-156. doi: 10.1111/j.1365-2958.1990.tb02025.x

Samuelsen, O. B., and Bergh, Ø (2004). Efficacy of orally administered florfenicol and oxolinic acid in the treatment of vibriosis in cod (Gadus morhua L.). Aquaculture 235, 27-35. doi: 10.1016/S0044-8486(03) 00446-0

Samuelsen, O. B., Bergh, Ø., and Ervik, A. (2003). A single-dose pharmacokinetic study of florfenicol in cod (Gadus morhua L.) held in seawater at $8^{\circ} \mathrm{C}$ and in vitro antibacterial activity against some Vibrio anguillarum strains isolated from diseased cod. Dis. Aquat. Org. 56, 127-133. doi: 10.3354/dao056127

Samuelsen, O. B., Hjeltnes, B., and Glette, J. (1998). Efficacy of orally administered florfenicol in the treatment of furunculosis in Atlantic salmon. J. Aquat. Anim. Health. 10, 56-61. doi: 10.1577/1548-8667 (1998)010<0056:EOOAFI >2.0.CO;2

Sapkota, A., Sapkota, A. R., Kucharski, M., Burke, J., McKenzie, S., Walker, P., et al. (2008).
Aquaculture practices and potential human health risks: current knowledge and future priorities. Environ. Int. 34, 1215-1226. doi: 10.1016/j.envint.2008.04.009

Schmidt, A. S., Bruun, M. S., Dalsgaard, I., and Larsen, J. L. (2001a). Incidence, distribution, and spread of tetracycline resistance determinants and integron-associated antibiotic resistance genes among motile aeromonads from a fish farming environment. Appl. Environ. Microbiol. 67, 5675-5682. doi: 10.1128/AEM. 67.12.5675-5682.2001

Schmidt, A. S., Bruun, M. S., Larsen, J. L., and Dalsgaard, I. (2001b) Characterization of class 1 integrons associated with R-plasmids in clinical Aeromonas salmonicida isolates from various geographical areas. J. Antimicrob. Chemother. 47, 735-743. doi: 10.1093/jac/47.6.735

Schwarz, S., Kehrenberg, C., Doublet, B., and Cloeckaert, A. (2004). Molecular basis of bacterial resistance to chloramphenicol and florfenicol. FEMS Microbiol. Rev. 28, 519-542. doi: 10.1016/j.femsre.2004.04.001

SERNAPESCA (Chile). (2009). Informe De Uso De Antimicrobianos 20052009. Report available at: http://www. sernapesca.cl/index.php?option= com_remository\&Itemid $=246 \&$ func $=$ select\&id=35\&orderby $=2 \&$ page $=2$.

Seyfried, E. E., Newton, R. J., Rubert, K. F., Pedersen, J. A., and McMahon, K. D. (2010). Occurrence of tetracycline resistance genes in aquaculture facilities with varying use of oxytetracycline. Microb. Ecol. 59, 799-807. doi: 10.1007/s00248-009-9624-7

Shah, S. Q., Nilsen, H., Bottolfsen, K., Colquhoun, D. J., and Sørum, H. (2012). DNA gyrase and topoisomerase IV mutations in quinolone-resistant Flavobacterium psychrophilum isolated from diseased salmonids in Norway. Microb. Drug Resist. 18, 207-214. doi: $10.1089 / \mathrm{mdr} .2011 .0142$

Shaw, W. V., and Leslie, A. G. (1991). Chloramphenicol acetyltransferase. Annu. Rev. Biophys. Biophys. Chem. 20, 363-386. doi: 10.1146/annurev.bb.20.060191. 002051
Smith, P. (2008). Aquaculture and florfenicol resistance in Salmonella enterica Typhimurium DT104 (letter). Emerg. Infect. Dis. 14, 1327-1328. doi: 10.3201/eid1408.080329

Sofia, H. J., Chen, G., Hetzler, B. G. Reyes-Spindola, J. F., and Miller, N. E. (2001). Radical SAM, a novel protein superfamily linking unresolved steps in familiar biosynthetic pathways with radical mechanisms: functional characterization using new analysi and information visualization methods. Nucleic Acids Res. 29, 1097-1106. doi: 10.1093/nar/29.5.1097

Sørum, H., L'Abee-Lund, T. M., Solberg, A., and Wold, A. (2003). Integron-containing inc $\mathrm{U} \mathrm{R}$ plasmid pRAS1 and pAr-32 from the fish pathogen Aeromonas salmonicida. Antimicrob. Agents Chemother 47, 1285-1290. doi: 10.1128/AAC. 47.4.1285-1290.2003

Speer, B. S., and Salyers, A. A. (1989). Novel aerobic tetracycline resistance gene that chemically modifies tetracycline. J. Bacteriol. 171, 148-153.

Speer, B. S., Shoemaker, N. B., and Salyers, A. A. (1992). Bacterial resistance to tetracycline: mechanisms, transfer, and clinical significance. Clin. Microbiol. Rev. 5, 387-399.

Su, H. C., Ying, G. G., Tao, R., Zhang, R. Q., Fogarty, L. R., and Kolpin, D. W. (2011). Occurrence of antibiotic resistance and characterization of resistance genes and integrons in Enterobacteriaceae isolated from integrated fish farms in South China. J. Environ. Monit. 13, 3229-3236. doi: $10.1039 / \mathrm{clem} 10634 \mathrm{a}$

Tao, W., Lee, M. H., Wu, J., Kim, N. H., Kim, J.-C., Chung, E., et al. (2012). Inactivation of chloramphenicol and florfenicol by a novel chloramphenicol hydrolase. Appl. Environ. Microbiol. 78, 6295-6301. doi: 10.1128/AEM. 01154-12

Taylor, D. E., and Chau, A. (1996). Tetracycline resistance mediated by ribosomal protection. Antimicrob. Agents Chemother. 40, 1-5.

Tirado, M. C., Clarke, R., Jaykus, L. A., McQuatters-Gollop, A., and
Frank, J. M. (2010). Climate change and food safety: a review. Food Res. Int. 43, 1745-1765. doi: 10.1016/ j.foodres.2010.07.003

Tran, J. H., and Jacoby, G. A. (2002). Mechanism of plasmidmediated quinolone resistance. Proc. Natl. Acad. Sci. U.S.A. 99, 5638-5642. doi: 10.1073/ pnas.082092899

Welch, T. J., Evenhuis, J., White, D. G., McDermott, P. F., Harbottle, H., Miller, R. A., et al. (2009). IncA/C plasmid-mediated florfenicol resistance in the catfish pathogen Edwardsiella ictaluri. Antimicrob. Agents Chemother. 53, 845846. doi: 10.1128/AAC.01312-08

WHO. (2011). Critically Important Antimicrobials for Human Medicine, 3rd Revision. Available at: http://apps.who.int/iris/ bitstream/10665/77376/1/978924150 4485_eng.pdf.

Conflict of Interest Statement: The authors declare that the research was conducted in the absence of any commercial or financial relationships that could be construed as a potential conflict of interest.

Received: 30 April 2013; paper pending published: 30 May 2013; accepted: 29 July 2013; published online: 22 August 2013.

Citation: Miranda CD, Tello A and Keen PL (2013) Mechanisms of antimicrobial resistance in finfish aquaculture environments. Front. Microbiol. 4:233. doi: 10.3389/fmicb.2013.00233

This article was submitted to Antimicrobials, Resistance and Chemotherapy, a section of the journal Frontiers in Microbiology.

Copyright (c) 2013 Miranda, Tello and Keen. This is an open-access article distributed under the terms of the Creative Commons Attribution License (CC BY). The use, distribution or reproduction in other forums is permitted, provided the original author(s) or licensor are credited and that the original publication in this journal is cited, in accordance with accepted academic practice. No use, distribution or reproduction is permitted which does not comply with these terms. 